\title{
MENINGKATKAN KINERJA GURU MELALUI SUPERVISI PEMBELAJARAN
}

\author{
Ubabuddin \\ Institut Agama Islam Sultan Muhammad Syafiuddin Sambas \\ ubabuddin@gmail.com
}

\begin{abstract}
Abstrak
Supervisi pada umumnya mengacu pada usaha perbaikan situasi pada proses belajar mengajar. Karena aspek utama adalah guru, maka layanan dan aktivitas kesupervisian harus lebih diarahkan kepada upaya memperbaiki dan meningkatkan kemampuan guru dalam mengelola kegiatan belajar mengajar. Supervisi merupakan usaha pejabat sekolah dalam memimpin guruguru dan tenaga kependidikan lainnya, untuk memperbaiki pengajaran termasuk menstimulasi, menyeleksi pertumbuhan dan perkembangan jabatan guru-guru, menyeleksi dan merevisi tujuan-tujuan pendidikan, bahan pengajaran, dan metode-metode mengajar serta evaluasi pengajaran. Supervisi di sekolah dilaksanakan oleh kepala sekolah yang bertindak sebagai supervisor, maka ia harus mampu melakukan berbagai pengawasan dan pengendalian untuk meningkatkan kinerja guru. Dalam melakukan supervisi, seorang supervisor hendaknya memperhatikan hal-hal penting, yaitu: (1) Proses pengawasan/supervisi meliputi dua hal, yaitu menetapkan standar-standar pelaksanaan pekerjaan dan pengukuran hasil/pelaksanaan pekerjaan, (2) informasi dan pengawasan, meliputi: (a) pengawasan sebagai suatu sistem informasi, (b) jenis-jenis informasi pengawasan, (c) pendekatan sistem dalam pengawasan. (3) pengawasan yang efektif didasarkan pada sistem informasi manajemen yang efektif, (4) evaluasi program, yaitu pembuatan pertimbangan menurut suatu perangkat kriteria yang disepakati dan dapat dipertanggung jawabkan, (5) prinsip-prinsip supervisi dengan suasana kemitraan, bersifat praktis, sistematis, objektif, realistis, bersifat bantuan, kreatif, antisipatif, konstruktif, dan kooperatif, (6) sasaran supervisi dapat mengenai kegiatan atau aspek yang disupervisi maupun orang yang melakukannya.
\end{abstract}

Kata Kunci: Supervisi Pembelajaran, Kinerja, Guru

\begin{abstract}
Supervision generally refers to efforts to improve the situation in the teaching and learning process. Because the main aspect is the teacher, the service and professional activities must be directed towards efforts to improve the ability of teachers to manage teaching and learning activities. Supervision is the effort of school stakeholders to lead teachers and other education personnel, to improve teaching including stimulating, selecting growth and development of teacher positions, selecting and revising educational goals, teaching materials, and teaching methods and teaching evaluation. Supervision in schools is carried out by the principal who acts as a supervisor, so he must be able to carry out various supervision and controls to improve teacher performance. In supervising, a supervisor should pay attention to important things, namely: (1) The process of supervision/supervision covers two things, namely setting standards for the implementation of work and measuring the results/implementation of work, (2) information and supervision, including: (a) supervision as an information system, (b) types of monitoring information, (c) system approach in supervision. (3) effective supervision is based on effective management information systems, (4) program evaluation, namely making judgements according to an agreed and accountable set of criteria, (5) the principles of supervision with a partnership atmosphere, practical, systematic, objective, realistic, helpful, creative, anticipatory, constructive, and cooperative, (6) supervision targets can be concerning activities or aspects supervised and those who do them.
\end{abstract}

Keywords: Learning Supervision, Performance, Teacher 


\section{PENDAHULUAN}

Peningkatan mutu pendidikan dari tahun ke tahun selalu diupayakan, baik pada pendidikan di tingkat dasar, menengah maupun pendidikan di perguruan tinggi. Pembenahan itu dilaksanakan di segala bidang antara lain berupa sarana/fasilitas, kurikulum, dan pendidik/guru. Apabila kita perhatikan tujuan pendidikan dalam sistem pendidikan nasional, yaitu membentuk manusia Indonesia seutuhnya dalam arti tersedianya SDM yang berkualitas, maka harus didukung oleh tenaga pendidik yang profesional. Profesionalisme pendidik akan bisa ditingkatkan bila didukung dengan adanya pengawasan, pembinaan dan pemberian bimbingan yang baik. Kegiatan utama pendidikan di sekolah dalam rangka mewujudkan tujuan tersebut adalah kegiatan pembelajaran sehingga seluruh aktivitas organisasi sekolah bermuara pada pencapaian efisiensi dan efektivitas pembelajaran. Pembelajaran seharusnya diselenggarakan secara interaktif, inspiratif dalam suasana yang menyenangkan, menggairahkan, menantang, memotivasi peserta didik untuk berpartisipasi aktif, serta memberikan ruang yang cukup bagi prakarsa, kreativitas, dan kemandirian sesuai bakat, minat, dan perkembangan fisik serta psikologis peserta didik. Semua itu diperlukan adanya standar proses pembelajaran.

Tugas pokok guru adalah menyusun perencanaan pembelajaran, melaksanakan pembelajaran, dan menilai hasil belajar siswa. Agar mutu pendidikan dapat dicapai secara optimal, maka pelaksanaan tugas pokok guru tersebut harus mendapat pengawasan, baik dari pengawas maupun kepala sekolah. Pengawasan proses pembelajaran adalah salah satu bentuk penjaminan mutu yang dilakukan secara internal (sekolah) untuk memberikan layanan bagi terjadinya proses pembelajaran yang efektif dan efisien. Sebagai bentuk pengawasan eksternal oleh pengawas, supervisi juga dapat difungsikan sebagai pengawasan internal, pengawasan proses pembelajaran menjadi tanggung jawab Kepala Sekolah selaku supervisor pembelajaran.
Sehubungan dengan itu, Kepala sekolah sebagai supervisor berfungsi untuk mengawasi, membangun, mengoreksi dan mencari inisiatif terhadap jalannya seluruh kegiatan pendidikan yang dilaksanakan di lingkungan sekolah. Secara teoritis supervisi merupakan suatu proses yang dirancang secara khusus untuk membantu para guru dalam menjalankan tugas-tugas sehari-hari di sekolah agar dapat menggunakan pengetahuan dan kemampuannya untuk memberikan layanan yang lebih baik kepada peserta didik. Depdiknas (1994) merumuskan supervisi sebagai berikut: "Pembinaan yang diberikan kepada seluruh staf sekolah agar mereka dapat meningkatkan kemampuan untuk mengembangkan situasi belajar mengajar yang lebih baik". Dengan demikian, supervisi ditujukan kepada penciptaan atau pengembangan situasi belajar mengajar yang lebih baik. Untuk itu ada dua hal (aspek) yang perlu diperhatikan: pertama, pelaksanaan kegiatan belajar mengajar; dan kedua, halhal yang menunjang kegiatan belajar mengajar.

\section{PEMBAHASAN \\ Pengertian Supervisi Pembelajaran}

Secara etimologi, supervisi berasal dari kata super dan visi yang artinya melihat dan meninjau atau menilik dan menilai dari atas yang dilakukan oleh pihak atasan terhadap aktivitas, kreativitas, dan kinerja bawahan (Jamal Ma'ruf Asmani, 2012: 19). Selanjutnya AN Ametembun (1991: 2) mengungkapkan bahwa: "Supervisi diambil dari perkataan Inggris supervision artinya pengawasan. Lebih lanjut diungkapkan bahwa istilah supervisi dapat pula dijelaskan menurut arti morfologis, supervisi terdiri dari dua patah kata yakni super dan visi. Super artinya atas dan visi artinya lihat, tilik, awasi. Seorang supervisor memang mempunyai posisi di atas atau mempunyai kedudukan yang lebih tinggi dari pada orang-orang yang disupervisinya".

Supervisi diartikan sebagai layanan yang bersifat membimbing, memfasilitasi, memotivasi serta menilai guru dalam pelaksanaan pembelajaran dan 
pengembangan profesinya secara efektif. Pengertian lain supervise pembelajaran diartikan sebagai "pelayanan yang disediakan oleh pemimpin untuk membantu guru-guru agar menjadi guru atau personal yang semakin cakap sesuai dengan perkembangan ilmu pengetahuan pada umumnya dan ilmu pendidikan khususnya, agar mampu meningkatkan efektivitas proses belajar mengajar di sekolah" (Nawawi, 1983: 104).

M. Ngalim Purwanto (2006: 76) mengungkapkan supervisi adalah suatu aktivitas pengawasan dan pembinaan yang direncanakan untuk membantu para guru dan pegawai sekolah lainnya dalam melakukan pekerjaan mereka secara efektif. Surya Dharma (2008: 7) dalam jurnalnya mengungkapkan: "Menurut konsep tradisional, supervisi dilaksanakan dalam bentuk inspeksi atau mencari kesalahan. Sedangkan dalam pandangan modern, supervisi merupakan usaha untuk memperbaiki situasi pendidikan atau pembelajaran, yakni sebagai bantuan bagi pendidik untuk meningkatkan kemampuan profesionalisme sehinnga peserta didik akan lebih berkualitas. Konsekuensi prilaku supervisi tradisonal atau snooper vision adalah para staf pengajar akan menjadi takut dan mereka bekerja secara terpaksa serta mengurangi/mematikan kreativitas guru/dosen dalam pengembangan profesionalismenya".

Atas dasar uraian di atas, maka pengertian supervisi dapat dirumuskan sebagai serangkaian usaha pemberian bantuan kepada guru dalam bentuk layanan profesional yang diberikan oleh supervisor (pengawas sekolah, kepala sekolah, dan pembina lainnya) guna meningkatkan mutu proses dan hasil belajar mengajar. Pembinaan guru lebih menekankan pada pembinaan kinerja guru yakni pembinaan yang lebih diarahkan pada upaya memperbaiki, memotivasi dan meningkatkan kemampuan kinerja guru dalam mendidik atau menyampaikan pembelajaran kepada peserta didik.

Aspek-aspek tersebut menuntut pengetahuan tentang konsep-konsep dan pendekatan supervisi yang ditunjang dengan kinerja serta akuntabilitas yang tinggi dari supervisor. Hal ini dimaksudkan agar kegiatan supervisi sebagai layanan profesional dapat meningkatkan kompetensi guru dalam pembelajaran yang bermuara pula pada perwujudan hasil belajar peserta didik secara optimal.

\section{Tujuan Supervisi Pembelajaran}

Tujuan umum supervisi adalah memberikan bantuan teknis dan bimbingan kepada guru dan staf agar personil tersebut mampu meningkatkan kualitas kinerjanya, dalam melaksanakan tugas dan melaksanakan proses belajar mengajar. Secara operasional dapat dikemukakan beberapa tujuan konkrit dari supervisi sebagaimana yang dipaparkan oleh Jerry. H. Makawimbang (2011: 75-76) yaitu:

1. Meningkatkan mutu kinerja guru.

2. Meningkatkan keefektifan kurikulum sehingga berdaya guna dan terlaksana dengan baik.

3. Meningkatkan keefektifan dan keefisian sarana dan prasarana yang ada untuk dikelola dan dimanfaatkan dengan baik sehingga mampu mengoptimalkan keberhasilan siswa.

4. Meningkatkan kualitas pengelolaan sekolah khususnya dalam mendukung terciptanya suasana kerja yang optimal dan selanjutnya siswa dapat mencapai prestasi belajar sebagaimana yang diharapkan.

5. Meningkatkan kualitas situasi umum sekolah sehingga tercipta situasi yang tenang dan tentram serta kondusif yang akan meningkatkan kualitas pembelajaran yang menunjukkan keberhasilan lulusan.

Sedangkan Bafadal (2008: 76) mengungkapkan bahwa tujuan supervisi adalah untuk membantu guru mengembangkan kemampuannya, mencapai tujuan pengajaran yang dicanangkan bagi murid-muridnya. Ibnu Syamsi (1988: 110) bahwa tujuan supervisi, yaitu untuk mengetahui:

1. Apakah suatu pelaksanaan itu berjalan sesuai dengan rencana yang telah digariskan?

2. Apakah segala sesuatu dijalankan sesuai dengan instruksinya? 
3. Kelemahan dan kesulitan dalam bekerja?

4. Mencari jalan keluar, bilamana terdapat kesulitan-kesulitan dan diusahakan pemecahannya.

Dalam usaha meningkatkan kualitas sumber daya pendidikan, guru merupakan komponen utama yang harus dibina dan dikembangkan terus menerus, sehingga dapat meningkatkan kinerja guru di sekolah. Disini dibutuhkan supervisor untuk mensupervisi semua persoalan yang muncul bagi guru dengan tujuan memberikan bantuan perbaiakan-perbaikan dengan semestinya. Dengan merefleksi semua tujuan inilah supervisi akan berfungsi dengan baik dan dapat mengubah perilaku mengajar dan meningkatkan kinerja guru. Pada gilirannya nanti perubahan perilaku mengajar dan kinerja guru ke arah yang lebih berkualitas akan menimbulkan perilaku belajar murid yang lebih baik.

\section{Fungsi Supervisi Pembelajaran}

Supervisi pembelajaran berfungsi untuk memperbaiki situasi pembelajaran melalui pembinaan profesionalisme guru. Briggs (dalam Sahertian, 2008: 25) menyebutkan fungsi supervisi sebagai upaya mengkoordinir, menstimulir dan mengarahkan pertumbuhan guru-guru. Supervisi pembelajaran memiliki fungsi penilaian (evaluation) yaitu penilaian kinerja guru dengan jalan pengamatan, yakni mengumpulkan informasi dan faktafakta mengenai kinerja guru dengan cara melakukan pengamatan. Kegiatan evaluasi dan pengamatan ini merupakan usaha perbaikan, sehingga berdasarkan data dan informasi yang mestinya sehingga dapat meningkatkan kualitas kinerja guru dalam pembelajaran (Sagala, 2010).

Pada beberapa kajian seperti yang diungkapkan oleh Gregorio (1966) dikemukakan bahwa lima fungsi utama supervisi antara lain berperan sebagai inspeksi, penelitian, pelatihan, bimbingan dan penilaian. Fungsi inspeksi antara lain berperan dalam mempelajari keadaan dan kondisi sekolah. Fungsi penelitian adalah mencari jalan keluar dari permasalahan yang sedang dihdapi, dan penelitian ini dilakukan sesuai dengan prosedur ilmiah, yakni merumuskan masalah yang akan diteliti, mengumpulkan data, mengolah data, dan melakukan analisa guna menarik suatu kesimpulan atas apa yang berkembang dalam menyusun strategi keluar dari permasalahan diatas.

Fungsi pelatihan merupakan salah satu usaha untuk memecahkan masalah yang sedang dihadapi, dan dalam pelatihan diperkenalkan kepada guru cara-cara baru yang lebih sesuai dalam melaksanakan suatu proses pembelajaran, dan jenis pelatihan yang dapat dipergunakan antara lain melalui demonstrasi mengajar, workshop, seminar, observasi, individual dan group conference, serta kunjungan supervisi.

Fungsi bimbingan sendiri dirtikan sebagai usaha untuk mendorong guru baik secara perorangan maupun kelompok agar mereka mau melakukan berbagai perbaikan dalam menjalankan tugasnya, dan bimbingan sendiri dilakukan dengan cara membangkitkan kemauan, memberi semangat, mengarahkan, dan merangsang untuk melakukan percobaan, serta membantu menerapkan sebuah prosedur mengajar yang baru.

Sedangkan fungsi penilaian adalah untuk mengukur tingkat kemajuan yang diinginkan, seberapa besar telah dicapai dan penilaian ini dilakukan dengan berbagai cara seperti tes, penetapan standar, penilaian kemajuan belajar siswa, melihat hasil penilaian sekolah serta prosedur lain yang berorientasi pada peningkatan mutu pendidikan.

Dari uraian diatas dapat disimpulkan bahwa fungsi supervisi pembelajaran mencakup: (1) perbaikan, (2) pengamatan atau penelitian, (3) pembinaan, (4) pengembangan, (5) koordinasi, memotivasi, dan (7) penilaian.

\section{Prinsip-prinsip Supervisi Pembelajaran}

Pengawas dalam melaksanakan supervisi hendaknya senantiasa menerapkan prinsip-prinsip supervisi sebagai berikut:

1. Prinsip Ilmiah dengan unsur-unsur:

a. Sistematis, berarti dilaksanakan secara teratur, berencana dan kontinyu. 
b. Obyektif, artinya data yang didapat berdasarkan pada observasi nyata, bukan tafsiran pribadi.

c. Menggunakan alat (instrumen) yang dapat memberikan informasi sebagai umpan balik untuk mengadakan penilaian terhadap proses belajar mengajar.

2. Demokratis, menjunjung tinggi atas musyawarah.

3. Kooperatif/kemitraan, seluruh staf dapat bekerjasama, mengembangkan usaha dalam menciptakan situasi pembelajaran dan suasana kerja yang lebih baik.

4. Konstruktif dan kreatif, membina inisiatif staf/guru serta mendorong untuk aktif menciptakan suasana agar setiap orang merasa aman dan dapat mengembangkan potensi-potensinya (Abd. Kadim Masaong, 2013: 9).

Selain prinsip-prinsip yang dikemukakan di atas, Rivai (1981) dalam Masaong (2013: 9) membagi prinsipprinsip supervisi atas dua bagian, yaitu prinsip positif dan prinsip negatif.

Prinsip-prinsip Positif

1. Supervisi harus konstruktif dan kreatif

2. Supervisi harus lebih berdasarkan sumber kolektif kelompok daripada usaha-usaha supervisi sendiri

3. Supervisi harus didasarkan atas hubungan profesional, bukan atas dasar hubungan pribadi

4. Supervisi harus dapat mengembangkan segi-segi kelebihan pada yang dipimpin

5. Supervisi harus dapat memberikan perasaan aman pada anggota-anggota kelompoknya

6. Supervisi harus progresif

7. Supervisi harus didasarkan pada keadaan yang riil dan sebenarnya

8. Supervisi harus sederhana dan informal dalam pelaksanaannya

9. Supervisi harus obyektif dan sanggup mengadakan self evaluation

Prinsip-prinsip Negatif

1. Supervisi tidak boleh bersifat mendesak/direktif

2. Supervisi tidak boleh didasarkan atas kekuasaan pangkat/kedudukan atau atas dasar kekuasaan pribadi

3. Supervisi tidak boleh dilepaskan dari tujuan pendidikan dan pengajaran
4. Supervisi tidak boleh terlalu banyak mengenai soal-soal yang mendetail mengenai cara-cara mengajar dan bahan pembelajaran

5. Supervisi tidak boleh mencari-cari kesalahan dan kekurangan staf/guru

6. Supervisi tidak boleh terlalu cepat mengharapkan hasil dan lekas kecewa

Prinsip-prinsip positif dan negatif ini harus menjadi acuan utama pengawas dalam menjalankan kegiatan supervisi di sekolah agar konstribusi supervisi terhadap pembelajaran membuahkan hasil yang optimal.

\section{Tugas dan Fungsi Supervisor}

Seorang supervisor perlu memahami bahwa kegiatan apapun yang dilakukannya bertujuan untuk memperbaiki proses dan hasil belajar mengacu pada terjadinya perubahan perilaku mengajar guru ke arah yang lebih baik. Untuk itu seorang supervisor harus memahami tugas dan fungsi sebagai supervisor seperti bagan di bawah ini:

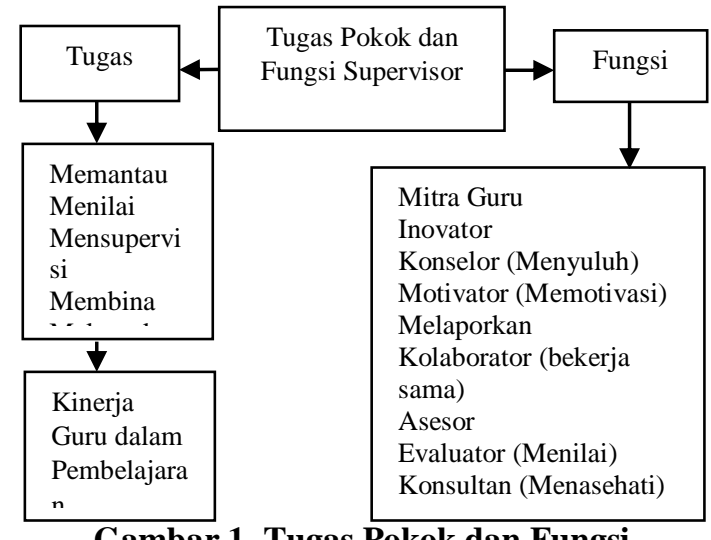

Gambar 1. Tugas Pokok dan Fungsi

$$
\text { Supervisor }
$$

Sumber: (Aqib, 2009: 6)

Dalam suatu analisa fungsi supervisi yang diberikan oleh swearingen yang dikutip Sahertian (2008: 21), terdapat 8 fungsi supervisi, yakni:

1. Mengkoordinasi Semua Usaha Sekolah.

Koordinasi yang baik diperlukan terhadap semua usaha sekolah untuk mengikuti perkembangan sekolah yang makin bertambah luas dan usaha-usaha sekolah yang makin menyebar, diantaranya: Usaha tiap guru, Usaha- 
usaha sekolah, Usaha-usaha pertumbuhan jabatan.

2. Memperlengkapi Kepemimpinan Sekolah.

Yakni, melatih dan memperlengkapi guru-guru agar mereka memiliki ketrampilan dan kepemimpinan dalam kepemimpinan sekolah.

3. Memperluas Pengalaman.

Yakni, memberi pengalamanpengalaman baru kepada anggotaanggota staff sekolah, sehingga selalu anggota staff makin hari makin bertambah pengalaman dalam hal mengajarnya.

4. Menstimulasi Usaha-Usaha yang Kreatif.

Yakni, kemampuan untuk menstimulir segala daya kreasi baik bagi anak-anak, orang yang dipimpinnya dan bagi dirinya sendiri.

5. Memberikan Fasilitas dan Penilaian yang Kontinyu.

Penilaian terhadap setiap usaha dan program sekolah misalnya, memiliki bahan-bahan pengajaran, buku-buku pengajaran, perpustakaan, cara mengajar, kemajuan murid- muridnya harus bersifat menyeluruh dan kontinyu.

6. Menganalisa Situasi Belajar

Situasi belajar merupakan situasi dimana semua faktor yang memberi kemungkinan bagi guru dalam memberi pengalaman belajar kepada murid untuk mencapai tujuan pendidikan.

7. Memberi Pengetahuan dan Ketrampilan pada Setiap Anggota Staf.

Supervisi berfungsi memberi stimulus dan membantu guru agar mereka memperkembangkan pengetahuan dan keterampilan dalam belajar.

8. Mengintegrasikan Tujuan dan

Pembentukan Kemampuan.

Fungsi supervisi di sini adalah membantu setiap individu, maupun kelompok agar sadar akan nilai-nilai yang akan dicapai itu, memungkinkan penyadaran akan kemampuan diri sendiri.

Ametembun (1991: 98) menyatakan seorang supervisor hendaknya melakukan fungsi-fungsinya sebagai berikut:
1. Penelitian, untuk memperoleh gambaran yang jelas dan objektif tentang suatu situasi pendidikan maka perlu diadakan penelitian yang seksama terhadap situasi itu.

2. Penilaian, supervisor dalam hal ini dapat menarik kesimpulan terhadap hasil penelitian yang diselidiki. Kesimpulan berupa tanggapan terhadap masalah atau situasi yang diselidiki itu dan terus melakukan penilaian. Fungsi penilaian atau evaluasi dalam hal ini adalah lebih menitik beratkan pada aspekaspekpositif (kebaikan-kebaikan) dari aspek-aspek negatif.

3. Perbaikan, dari hasil penelitian itu supervisor dapat mengetahui bagaimana keadaan suatu situasi pendidikan/pengajaran pada umumnya dan pendidikan/pengajaran pada khususnya, serta segala fasilitas dan daya upaya yang dipergunakan, apakah baik atau buruk, memuaskan atau tidak, mengalami kemajuan atau kemunduran, atau mengalami kemacetan dan sebagainya.

4. Peningkatan, bagaimana dengan situasi yang sudah baik, sudah memuaskan, telah mengalami kemajuan itu. Situasi yang demikian harus ditingkatkan atau dikembangkan agar apa yang sudah memuaskan itu supaya lebih memuaskan lagi.

Sejalan dengan fungsi supervisor diatas, Jerry H. Makawimbang (2011: 85) membagi fungsi supervisor menjadi fungsi umum dan fungsi khusus, seperti berikut ini:

1. Fungsi Umum Supervisor
a. Pemantauan
b. Penyeliaan (supervision)
c. Pengevaluasian
d. Penindak lanjutan hasil pengawasan

2. Fungsi Khusus Supervisor

Kemitraan, pembaharuan, pemeloporan, konsultan, pembimbingan, pemotivasian, pengonsepan, pemrograman, penyusunan, pelaporan, pembinaan, pendorongan, pemantauan, pemanfaatan, pengawasan, pengkoordinasian, dan pelaksanaan kepemimpinan. 
Seorang supervisor perlu memahami dengan jelas fungsi supervisi akademik yang dipercayakan kepadanya dalam usaha kearah tercapainya tujuan. Sehingga pelaksanaan supervisi yang dilaksanakan oleh supervisor dapat berjalan sesuai dengan perencanaan yang disusun

\section{Peningkatan Kinerja Guru Melalui Pelaksnaan Supervisi Pembelajaran Kinerja Guru}

Menurut Mulyasa (2013: 88) "Kinerja adalah unjuk kerja seseorang yang ditunjukkan dalam penampilan, perbuatan, dan prestasi kerjanya sebagai akumulasi dari pengetahuan, keterampilan, nilai, dan sikap yang telah dimilikinya".

Menurut wibowo (2007: 7) kinerja adalah tentang melakukan pekerjaan dan hasil yang dicapai dari pekerjaan tersebut. Dan kinerja adalah tentang apa yang dikerjakan dan bagaimana cara mengerjakannya. Menurut Malayu (2005: 34) kinerja (prestasi kerja) adalah suatu hasil kerja yang dicapai seseorang dalam melaksanakan tugas-tugas yang dibebankan kepadanya yang didasarkan atas kecakapan, pengalaman dan kesungguhan serta waktu.

Menurut Rivai (2004: 309), kinerja guru adalah: perilaku nyata yang ditampilkan oleh guru sebagai prestasi kerja berdasarkan standar yang ditetapkan dan sesuai dengan perannya di sekolah.

Peran guru yang dimaksud adalah berkaitan dengan peran guru dalam proses pembelajaran. Guru merupakan faktor penentu yang sangat dominan dalam pendidikan pada umumnya, karena guru memegang peranan dalam proses pembelajaran, dimana proses pembelajaran merupakan inti dari proses pendidikan secara keseluruhan. Guru merupakan perencana, pelaksana sekaligus sebagai evaluator pembelajaran di kelas.

Kinerja guru menurut Mulyasa (2013: 88), adalah "suatu upaya untuk memperoleh gambaran tentang pengetahuan, keterampilan, nilai, dan sikap guru dalam melaksanakan tugas dan fungsinya, yang ditunjukkan dalam penampilan, perbuatan, dan prestasi kerjanya". Melihat beberapa pendapat diatas, dapat ditarik kesimpulan bahwa kinerja guru adalah proses pencapaian tugas yang menjadi tanggungjawab guru baik yang berkaitan langsung dengan kegiatan pembelajaran maupun yang tidak berkaitan langsung dengan proses pembelajaran untuk mencapai tujuan pendidikan yang diharapkan. Penilaiannya dapat melalui hasil dari kerja yang dilakukan oleh guru tersebut, contohnya saja administrasi belajar yang dibuat seperti RPP, serta dapat berupa pengamatan yang dilakukan setiap harinya.

\section{Indikator Penilaian Kinerja Guru}

Penilaian kinerja guru pada hakekatnya merupakan suatu kegiatan untuk membina dan mengembangkan guru profesional yang dilakukan oleh guru dan untuk guru. Peraturan Menpan dan reformasi birokrasi nomor 16 tahun 2009, menegaskan bahwa penilaian kinerja guru adalah penilaian dari tiap butir kegiatan tugas utama guru dalam rangka pembinaan karir, kepangkatan, dan jabatannya. Dalam pada itu dikemukakan bahwa penilaian kinerja guru dilakukan secara rutin setiap tahun yang menyoroti kompetensi bagi guru pembelajaran, serta pelaksanaan tugas tambahan lain yang relevan dengan fungsi sekolah/madrasah.

Berikut adalah indikator penilaian kinerja guru (Mulyasa, 2011: 30):

Aspek Pedagogik

1. Guru dapat mengidentifikasi karakteristik belajar siswa

2. Guru berusaha membantu dan mengembangkan potensi dan mengatasi kekurangan peserta didik

3. Guru memberikan kesempatan terhadap siswa untuk menguasai materi sesuai usia dan kemampuannya melalui pengaturan proses pembelajaran dan aktivitas yang bervariasi

4. Guru menggunakan berbagai teknik untuk memotivasi belajar siswa

5. Guru memperhatikan respon siswa yang belum/kurang memahami materi pembelajaran yang diajarkan dan menggunakannya untuk memperbaiki rancangan pembelajaran berikutnya. 
6. Merancang rencana pembelajaran yang sesuai dengan silabus untuk membahas materi ajar

7. Memilih materi pelajaran yang sesuai dengan tujuan, tepat dan mutakhir sesuai usia siswa dan dapat dilaksanakan di kelas sesuai konteks kehidupan sehari-hari

8. Mengkomunikasikan informasi baru (misalnya materi tambahan) sesuai dengan usia siswa dan tingkat kemampuan belajar siswa

9. Melakukan aktivitas pembelajaran secara bervariasi dengan waktu yang cukup untuk kegiatan pembelajaran yang sesuai dengan usia dan kemampuan belajar siswa dan memperhatikan perhatian peserta didik

10. Memberikan banyak kesempatan kepada siswa untuk bertanya, mempraktikkan, dan berinteraksi dengan peserta didik lain

11. Menganalisis hasil belajar berdasarkan segala bentuk penilaian terhadap setiap peserta didik untuk mengetahui tingkat kemajuan masing-masing.

12. Menanggapi pertanyaan siswa secara tepat, benar, mutakhir, sesuai tujuan pembelajaran dan isi kurikulum tanpa mempermalukannya.

Aspek Sosial

1. Menyajikan kegiatan pembelajaran yang dapat menumbuh kembangkan kerjasama yang baik antar peserta didik

2. Menyusun alat penilaian yang sesuai dengan tujuan pembelajaran untuk mencapai kompetensi tertentu seperti yang tertulis dalam RPP

3. Menganalisis hasil penilaian untuk mengidentifikasi kompetensi dasar

4. Mengembangkan kerjasama dan membina kebersamaan dengan teman sejawat tanpa memperhatikan perbedaan yang ada

5. Menghargai dan mempromosikan prinsip-prinsip pancasila sebagai dasar ideologi dan etika bagi semua warga Indonesia

Aspek Kepribadian

1. Bertingkahlaku sopan dalam berbicara, berpenampilan, dan berbuat baik terhadap semua siswa, orang tua, dan teman sejawat

2. Berperilaku baik untuk mencitrakan nama baik sekolah

3. Mengawali dan mengakhiri pembelajaran dengan tepat waktu

4. Meminta izin dan memberitahukan sebelumnya dengan memberikan alasan dan bukti yang sah jika tidak dapat menghadiri kegiatan yang telah direncanakan, termasuk proses belajar mengajar dikelas

5. Memperlakukan semua siswa dengan adil, memberikan perhatian, dan bantuan sesuai kebutuhan masingmasing tanpa memperdulikan faktor personal

Aspek Profesional

1. Menjaga hubungan baik dan peduli dengan teman sejawat, serta berkonstribusi positif terhadap semua diskusi formal dan informal terkait pekerjaan

2. Berinteraksi dengan peserta didik dan tidak membatasi perhatiannya hanya pada kelompok tertentu

3. Memperhatikan sekolah sebagai bagian dari masyarakat, berkomunikasi dengan masyarakat sekitar, serta berperan dalam kegiatan sosial di masyarakat

4. Menyertakan informasi yang tepat dan mutakhir di dalam perencanaan dan pelaksanaan pembelajaran

5. Menyusun materi perencanaan dan pelaksanaan pembelajaran yang berisi informasi yang tepat, mutakhir, dan yang membantu peserta didik untuk memahami konsep materi pelajaran

6. Melakukan evaluasi diri secara spesifik, lengkap, dan didukung dengan contoh pengalaman diri sendiri

\section{Peningkatan Kinerja Guru Melalui Supervisi}

Dalam pelaksanaan supervisi akan terdapat dua pihak yang melakukan hubungan kegiatan yaitu pihak supervisor dan pihak yang disupervisi. Pihak yang disebut pertama melakukan kegiatan pelayanan professional untuk membantu atau membimbing pihak yang dilayani. Pihak yang melayani terdiri dari supervisor 
fungsional (Pengawas) dan kepala sekolah. Pihak yang disebut kedua, yang disupervisi , ialah para guru sebagai pelaksana pendidikan. Mereka adalah orang yang terlibat langsung dalam proses pembelajaran. Pihak yang disebut kedua inilah yang menerima pelayanan professional berupa bantuan dan bimbingan dari pihak pertama agar mereka dapa meningkatkan kemampuan dalam melaksanakan proses pembelajaran secara efisien dan efektif. Melalui supervisi pengajaran guru akan semakin mampu memfasilisasikan belajar bagi peserta didiknya.

Dari uraian di atas, supervisi mempunyai tiga kegunaan. Pertama, supervisi berguna untuk meningkatkan kemampuan supervisor dalam memberikan bimbingan dan arahan. Kemampuan ini diperoleh supervisor apabila supervisor mengalami atau melaksanakan langsung supervisi tersebut secara kontinyiu. Kedua, meningkatkan kemampuan profesional guru dalam melaksanakan proses pembelajaran. Ketiga, menyusun pedoman dan petunjuk dalam memberikan bimbingan dan bantuan agar tercapainya tujuan yang diharapkan.

Untuk menyusun pedoman tersebut diperlukan informasi misalnya, supervisi akan mencapai tingkat kegunaan yang tinggi apabila kegiatannya dilakukan melalui tiga prinsip hubungan kemanusiaan (Sudjana, 2009: 240).

Ketiga prinsip ini adalah pengakuan dan penghargaan, objektivitas, dan kesejawatan. Hubungan kemanusiaan mengisyaratkan supervisi dilakukan secara wajar, terbuka dan partisipatif. Pengakuan dan penghargaan berkaitan dengan sikap supervisor untuk mengakui potensi dan penampilan para guru dan menghargai

\section{DAFTAR PUSTAKA}

Ametembun. 1991. Supervisi Pendidikan: Penuntun bagi para penilik Pengawas Kepala Sekolah dan Guru. Bandung: Suri Bandung.

Aqib. 2009. Penelitian Tindakan Sekolah untuk Pengawas, Kepala Sekolah dan Guru. Rama Widya: Bandung. bahwa guru dapat dan harus mengembangkan diri mereka untuk meningkatkan kinerja di sekolah.

\section{SIMPULAN}

Pelaksanaan supervisi pembelajaran diharapkan dapat memperbaiki kualitas pendidikan itu sendiri, sehingga segala bentuk tujuan dapat tercapai secara efektif dan efisien, terutama bagi guru. Karena guru dalam melaksanakan tugas tidak bisa terlepas dari segala bentuk masalah yang dihadapi. Disinilah supervisi pembelajaran sangat dibutuhkan oleh guru, agar dapat membantu menyelesaikan permasalahan yang dihadapinya.

Dalam melakukan supervisi, seorang supervisor hendaknya memperhatikan halhal penting, yaitu: (1) Proses pengawasan/supervisi meliputi dua hal, yaitu menetapkan standar-standar pelaksanaan pekerjaan dan pengukuran hasil/pelaksanaan pekerjaan, (2) informasi dan pengawasan, meliputi: (a) pengawasan sebagai suatu sistem informasi, (b) jenisjenis informasi pengawasan, (c) pendekatan sistem dalam pengawasan. (3) pengawasan yang efektif didasarkan pada sistem informasi manajemen yang efektif, (4) evaluasi program, yaitu pembuatan pertimbangan menurut suatu perangkat kriteria yang disepakati dan dapat dipertanggung jawabkan, (5) prinsip-prinsip supervisi dengan suasana kemitraan, bersifat praktis, sistematis, objektif, realistis, bersifat bantuan, kreatif, antisipatif, konstruktif, dan kooperatif, (6) sasaran supervisi dapat mengenai kegiatan atau aspek yang disupervisi maupun orang yang

melakukannya.

Bafadal, Ibrahim. 2008. Manajemen Peningkatan Mutu Berbasis Sekolah. Malang: Kerjasama FIP UM dan Ditjen-Dikdasmen.

Bafadal, Ibrahim. 2000. Supervisi pengajaran: teori dan aplikasinya dalam membina profesional. guru. Jakarta: Bumi Aksara. 
Dharma, Surya. Peran dan Fungsi Pengawas Sekolah/Madrasah. Dalam Jurnal Tenaga Kependidikan Volume 3, No. 1, April 2008.

Depdiknas, 1994. Tentang standar pengawas pendidikan nasional.

Ma'ruf Asmani, Jamal. 2012. Tips Efektif Supervisi Pendidikan Sekolah. Jogjakarta: DIV A Press.

Makawimbang, Jerry H. 2011. Supervisi dan Peningkatan Mutu Pendidikan. Bandung: Alfabeta.

Masaong, Abdul Kadim 2013. Supervisi Pembelajaran dan Pengembangan Kapasitas Guru, Memberdayakan Pengawas sebagai Gurunya Guru. Bandung: Alfabeta.

Nawawi, Hadari. 1983. Administrasi Pendidikan. Jakarta: Armas Duta Jaya.
Purwanto, Ngalimin. 2006. Administrasi dan Supervisi Pendidikan, Bandung: PT. Remaja Rosyda Karya. Cet Ke-18.

Sagala, Syaiful. 2010. Supervisi Pembelajaran. Dalam Profesi Pendidikan. Bandung, Alfabeta.

Sahertian. 2000. Konsep dasar dan tehnik supervisi pendidikan dalam rangka pengembangan sumber daya manusia. Jakarta: Rineka Cipta.

Sahertian. 2008. Supervisi Pendidikan dalam rangka Program Inservice Education. Jakarta: Penerbit Rineka Cipta.

Sujana, Nana. 2009. Supervisi Akademik Membina Profesionalisme Guru Melalui Supervisi Klinis. LPP Bina Mitra. Jakarta. 2008.

Syamsi, Ibnu. 1988. Pokok-pokok Organisasi dan Manajemen. Jakarta: Bina

Aksara. 